UDC 316.342.6.349

DOI: $10.21668 /$ health.risk/2018.3.03.eng

\title{
VULNERABILITY AS A SPECIFIC CATEGORY OF CONSUMER RISK
}

\section{L.N. Osaulenko}

Eurasian Economic Commission, Bldg. 1/2 Letnikovskaya Str., Moscow, 115114, Russian Federation

Regulation of legal relationships involving consumers which is adopted in the Eurasian Economic Union countries doesn't highlight peculiarities related to providing consumer rights of specific population groups; people who belong to such groups can't evaluate a situation correctly when they act as consumers due to various reasons, such as their age, physical peculiarities, or some other circumstances.

The author performed this research on the following object: legal relationships which exist between subjects acting on a consumer market, one party here being a consumer who is more vulnerable than others around due to his or her age or disability.

The research goal was to give a definition for "vulnerability" as a specific category of consumer risk which determines basic mechanisms of consumer rights protection.

To achieve this, the author analyzed and assessed consumer risks which occur in such situations when consumers are under a certain age, elderly people, or disabled people. The paper also dwells on some peculiarities of deals which are made by people from the above-mentioned population groups.

The performed research allowed to characterize a consumer "vulnerability" as an increased risk that a deal made by a consumer can have negative consequences due to his or her social or behavioral peculiarities. These peculiarities are shown to influence a person's ability to obtain or understand information; to make a free choice on a product or service; to perceive certain marketing practices adequately (perception of aggressive advertising); being financially capable to make deals. It was proved that specific population groups (young or elderly people, disabled people) are especially prone to consumer risks due to their age or physiologic peculiarities. People from such groups are too gullible and usually unable to adequately estimate all the consequences of a deal they have just made; they can also have limited physical abilities to fulfill their right to cancel a deal they made in due time.

Having performed this research, the author came to a conclusion that it is advisory to spot out specific groups of "vulnerable" consumers in order to protect their rights in a more proper way; it is necessary to supplement legislation on consumer rights protection with specific norms which can help to protect their rights and legitimate interests. As all the EEU countries are now trying to integrate their development processes, common grounds and approaches to national legislation development should be found in international legal acts adopted by the Eurasian Economic Union (EEU).

Key words: consumer, consumer behavioral risks, consumer protection, disabled people, elderly people, underage people, consumer risks, risk assessment, vulnerability, the Eurasian Economic Union legislation.

Consumer risk is given little attention as an issue to be examined; but simultaneously it is a rather complicated category that includes physical, economic, social, legal, and behavioral aspects. There are several types of consumer risks described in scientific works; they are physical (physiological), property, and economic ones [1$3]$. If we consider a consumer risk to be a specific barrier that prevents a consumer from complete fulfillment of his or her rights, it is advisable to start examining the issue from a physical (physiological) aspect of consumer vulnerability. Such definitions as "vulnerability" and "vulnerable groups" are used in many spheres associated with social relations and their essence tends to vary depending on a particular sphere. As regards consumer rights protection, experts on consumer risks are of the opinion that a level of risk directly depends on factors that influence consumer behavior: conditions of a deal not being well-defined; amount of knowledge and information a consumer has on the matter; occurrence of hazards, and adequate estimation of a situation and possible damage by consumers themselves [4].

Given all the above said, consumer vul-

(C) Osaulenko L.N., 2018

Lidiya N. Osaulenko - Candidate Of Jurisprudence, Head of Consumer Rights Protection Division at Department for Sanitary, Phytosanitary and Veterinary Measures (e-mail: osaulenko@eecommission.org; tel.: +7 (495) 669-24-00 (ext. 5180)). 
nerability can be defined as an increased risk that a deal made by a consumer can have negative consequences due to his or her social or behavioral peculiarities. These peculiarities influence a possibility to get free access to information, to make a free choice on a product or a service, to adequately perceive specific marketing information (susceptibility to aggressive advertising), a financial capability to make a deal (susceptibility to unfair practices when loan commitments are imposed on a consumer who is not able to pay for a product or a service with available financial resources).

This characteristics allows to examine a situational essence of risks and consumer vulnerability, and it means that 1) consumer "vulnerability" directly depends on a specific situation which a consumer is in; 2) certain consumer groups can be exposed to greater risks in comparison with others.

This research considers the following consumer groups to be "vulnerable": elderly people, disabled people, and young people. This differentiation is determined by objective factors that make these consumer groups "vulnerable". Among such factors there are specific needs that are to be satisfied for complete fulfillment of consumer rights (a consumer is not always able to adequately estimate conditions of a deal or quality of a product he or she buys due to his or her physical and mental abilities, or age) and peculiarities related to protecting rights of such consumer groups (they are not able to defend their rights themselves, and they don't understand basic principles of protection applied in situations when their rights are violated). The above-mentioned circumstances predetermine higher risks for such consumers concerning violations of their consumer rights and legal interests.

As a rule, consumers who belong to the above mentioned groups don't focus their attention on safety as a primary factor influencing their choice of a product or a service. Unfortunately, safety becomes the most significant in such situations when a consumer has to face consequences of a deal when he or she bought a hazardous product or a service. Thus, specific risks are caused for children, elderly people, and disabled people because they, due to their physiological peculiarities, most strongly react to neg- ative impacts caused by nutrition-related factors. Nutrition-related diseases lead to such serious outcomes as renal and hepatic failure, disorders in the brain and nervous system functioning, reactive arthritis, cancer, and death. As per the WHO estimation, diseases caused by low quality food and water annually result in 2.2 million deaths, most of the deceased being children [5].

Electronic commerce (or e-commerce for short) is another sphere where specific consumer risks can occur. Each 7th online purchase involving cross-border transaction entails impossibility to detect a person responsible for consumer rights observance. As services are rendered by a number of providers working together, it is sometimes hard to determine who is responsible - a seller, an Internet provider, a device itself, or a channel. As for electronic sales, there are also several participants in the process, starting from payment services providers to a national mail service, and it is too difficult to determine who is responsible for a quality of a product or a service.

And finally, direct deals between consumers are becoming more and more popular, and it makes the issue even more complicated as here we actually can't find a particular company that renders a service. This international labyrinth of transactions and purchases makes a determination of people responsible for sales of low quality products next to impossible. Thus, the repost issued by the Organization for Economic Cooperation and Development (OECD) stated that $68 \%$ goods sold via the Internet and detected by inspections were forbidden for sales in offline retail outlets [6].

All the above mentioned means it is hard for consumers to protect their rights, and it is practically next to impossible for people with age or physical peculiarities.

As practice shows, legislation adopted in the Eurasian Economic Union countries (EAEU) that regulates relations in the sphere of consumer rights protection is quite generalized and covers all the consumers without any vulnerable consumer categories being singled out. But at the same time contemporary development of social relations implies that certain differentiation in the sphere of consumer right protection is necessary.

According to a definition adopted by the WHO, disabled people are people with limited capabilities who face functional difficulties due to 
a disease, deviations, or development malformations, health state, or appearance; their capabilities can also be limited because the environment is not adapted to their specific needs or due to prejudices that a society has in relation to disabled people [7]. As per statistic data collected by the WHO, more than 1 billion people all over the world have this or that disability. It is rather frightening that disability figures are growing rapidly due to population aging and global increase in chronic diseases. It accounts for approximately $15 \%$ of the world population (from 110 to 190 million adult people) [8].

In order to reduce impacts exerted by these limitations, the EAEU member-states develop systems of state guarantees on social protection of disabled people that include a) creation of equal possibilities for such people to fulfill their economic, social, cultural, personal, and political rights; b) elimination of limitations on their life activity in order to recover their social status and to help them achieve material independence.

But still, consumer risks for disabled people are often related to limited physical possibility to buy a product due to absence of available infrastructure in retail outlets or due to absence of information about a product which is provided in a way convenient for understanding by people with sensory functions disorders.

We should also mention absence of information about peculiarities related to use of a product by disabled people among consumer risks for them.

Besides, as practice shows, people with limited capabilities often become victims of discrimination, especially by transport companies (it is especially widely spread in case of airlines), when they are refused transportation.

In many EAEU countries it is impossible to acknowledge a disabled person to be a consumer in situations when deals in favor of disabled people are made at the expense of insurance companies or social protection authorities. The issues requires consideration and solving at the legislative level.

Earlier, issues related to protection of elderly consumers rights were not given any special attention. Meanwhile, as per data provided by the WHO, a number of people aged 60 and older will grow from 900 million in 2015 to 2 billion in
2050 (from $12 \%$ to $22 \%$ of the overall world population).

Population aging is becoming faster and faster. Thus, for example, it took France more than 150 years to adapt to a growth in a share belonging to elderly people in the overall population from $10 \%$ to $20 \%$; it will take such countries as Brazil, India, or China just a bit longer than 20 years to adapt to the same changes [9].

A drastic increase in a share of elderly people in the overall world population calls for reconsideration of attitudes towards protection of their rights to consume products or services that are suitable for use taking into account individual peculiarities of such people.

Elderly people, due to their physical and mental age-related peculiarities, can often become victims of circumstances. While still being legally capable at the moment a deal is made, they often don't fully understand the meaning of their actions or they are unable to manage them properly. In this case a deal can be acknowledged as being invalid by court in accordance with the civil legislation.

Mental disorders are widely spread among people older than 60 . As per the WHO data, more than $20 \%$ people aged 60 and older suffer from mental or neurologic disorders ( excluding disorders related to headache), and $6.6 \%$ disabilities among people older than 60 are caused by neurologic and mental disorders. Dementia and depression are the most widely spread neuropsychiatric disorders among people belonging to this age group [10].

According to experts research performed in the Russian Federation ${ }^{1}$, disputed deals made by elderly people most frequently included the following: sales contracts (22.12\%) and deeds of gift $(22.12 \%)$, last wills $(38.46 \%)$, renunciation of inheritance $(2.88 \%)$, giving a power of attorney to dispose of property $(3.85 \%)$, order to withdraw a last will $(0.96 \%)$, a contract on a rent with life-long residence (7.69\%), a contract on non-repayable transfer of a share in a LLC authorized capital $(0.96 \%)$, and a contract on handing over a living space into ownership $(0.96 \%)^{1}$.

Besides, people belonging to this group of vulnerable consumers face another serious problem, or so called "discrimination" when elderly people are not treated by financial organizations as a priority target group and consequently they 
become the most financially excluded population group.

Thus, as per data of research performed in Russia in 2016, payments for communal services were the most popular financial service among elderly citizens. It was detected that $40 \%$ elderly people didn't use plastic cards, $70 \%$ didn't have a bank account except one for pension payments, 91\% didn't bought insurance services, and 93\% never bought products or services in the Internet [11].

Apart from some objective barriers (low incomes, limited access to digital products, low consumer and digital literacy, physical inaccessibility for people with limited abilities) there are also subjective ones (psychological barriers as understanding of one's' incompetence, a fear to make a mistake or to become a victim of a fraud, unwillingness to master new technologies etc.).

Children with their specific habits and preferences are another specific consumer group. And it is important to note that their habits and preferences are often formed not by their parents but by commercials, TV, or the Internet. More and more children aged 3-12 have their own TV set and their own gadget and are active users of social Internet networks. Children buy products themselves and can act both as direct consumers (even at such an early age as 3-5) and as major and active mediators in the process of buying. Children's habits and preferences influence consumer behavior of their parents thus creating a consumer basket of a family. Adult people often choose an internet-content depending on their children's preferences.

Basic consumer risk here is that children most frequently become victims of unfair marketing in online games, mobile applications, and social media-sites. As practice shows, most online games downloaded via popular applications contain built-in or context advertising (regardless of whether a game is free or it was paid for). Consumers of such game content frequently have to pay additional fees to get rid of advertising. Most games also include offers a consumer has to pay for (to buy a game continuation, or bonuses necessary to continue a game). Therefore, a child (being partially capable) is involved into making a deal which is not always approved by his parents.

These are only several aspects that call for necessity to develop specific regulation related to protection of specific "vulnerable" consumers.

Another risk existing for childrenconsumers in the Internet is related to so called "free" content that is often given in exchange for personal data; parents' control over purchase of such content is practically impossible in spite of the fact that they are actual buyers here. That is, a child can download "free" content (which can be hazardous for a child's psyche) without any preliminary check by parents who would like to make sure that this content is appropriate in terms of a child's age, development, culture, etc.

Lack of attention paid to vulnerable customer groups has become obvious recently, especially under globalization and constantly increasing necessity to develop comparable international legal regulation and specific mechanisms for consumer rights protection concerning various groups of population.

Despite a lot of works on examining risks related to consumption and behavioral peculiarities of consumers $[2,3,12]$, an issue of protecting consumer rights of disabled people and socially vulnerable population groups was first raised on the international level only in the revised "UN Guidelines for Consumer Protection" approved by the UN General Assembly in 2015 [13].

National strategies developed in the EAEU countries also include the issue into priority lists; in particular, "The strategy for the state policy in the sphere of consumer rights protection in the Russian Federation for the period up to 2030"2.

In 2018, when the Russian Federation has taken presidency over the EAEU, issues related to development of human potential, cooperation in social and humanitarian sphere and protection of public interests have been declared as the most significant trends in the further development of the Eurasian integration ${ }^{3}$.

Development of harmonized EAEU policy in the sphere of consumer rights protection is based on national legislation harmonization taking into account legal acts adopted by the Eura-

${ }^{1}$ Tyul'kina O.Yu. Forensic-psychiatric expertise of organic mental disorders in elderly people who made property deals: abstract of a thesis for ... Candidate of Medical Sciences. Moscow, 2013, pp. 6.(in Russian). 
sian Economic Commission. Recommendations given by the Commission to the EAEU member states are a "soft" administrative mechanism that will allow to implement unified regulation of the consumer rights protection on the whole EAEU territory.

Development of common approaches to protecting rights of vulnerable consumer groups is a new line in the EAEU countries cooperation; it is of great interest both for population (people are sure they purchase a qualitative product or service) and for business (companies can attract more consumers, products manufactures in the EAEU are popularized, imports are replaced).

Finding solutions to problems of disabled people and other socially vulnerable consumers are an unconditional priority and uniqueness of a document that determines unified approaches to protecting rights of specific consumer groups adopted in the EAEU countries.

There are not many examples of specific protection given to such people in world practice; development of a system approach to improvement of their situation can be considered advanced and unique experience.

Nowadays there are no unified (standard) solutions to problems in the sphere of protecting rights of vulnerable consumers in the EAEU countries. Therefore, development of common measures aimed at greater consumer safety in the EAEU countries should take into account aspects of protecting rights of vulnerable consumers in specific spheres of legal relations associated with considerable consumer risks. Such aspects include:

- issues related to provision of information about application and storage of a product (if it is unsafe for a consumer) when a product (service) is sold;

- advertising; notably, elimination of unfair communicative influences (aggressive advertising or advertising that influences specific consumer groups such as children or people who can't adequately estimate and understand their actions and their outcomes) that can cause a damage to consumers; ban on advertising of specific products (tobacco and alcohol in sensitive spheres or in contents oriented at children, teenagers, elderly or disabled people); creations of standards for advertising in the financial sphere;

- the financial sphere concerning availability of bank operations (comprehension of financial risks, restructuring of accounts payable for specific population groups);

- issues related to protection of young consumers when they use communicative technologies (smartphones, pads, or computers);

- updating of electronic commerce and greater digital literacy;

- a prohibition to discriminate vulnerable consumers (no one can be refused to make a deal with on the basis of his or her "vulnerability");

- development of transportation and tourism.

Besides, specific requirements to protec-

tion of vulnerable consumers should be introduced at all the stages in a product (service) life cycle:

- manufacturing: specific marking should be made on a product that helps people with limited abilities perceive information about it or that contains additional information if it is required by legislation of those countries where this product will be sold;

- pre-sale stage: a consumer should be given information about peculiarities related to safe use of a consumer product, about a product being appropriate for consumers of a certain age (age limitation), about possible suffocation, about noise levels, a product composition or any other possible hazards; a consumer should be given clear instructions on how to operate a product so that he or she can determine obvious possible hazards before he or she starts using it;

- operation: a consumer should be given a clear and easily comprehended instruction (taking into account requirements existing for specif-

${ }^{2}$ On Approval of the strategy for the RF state policy in the sphere of consumer rights protection for the period up to 2030: The RF Governmental Order issued on August 28, 2017 No. 1837-r. Official internet-portal of legal information. Available at: http://www.pravo.gov.ru (access date: 08.06. 2018) (in Russian).

${ }^{3}$ The Message by the RF President to the heads of the Eurasian Economic Union member states. The RF President: official internet-portal. Available at: http://kremlin.ru/events/president/news/56663 (access date: 08.06. 2018) (in Russian). 
ic consumer groups, for example, Braille, a voice message, etc.) on how to assemble a product and use it safely, information on safe maintenance, storage, lifetime, and utilization of a consumer product, and any other necessary service information.

Development of public interests protection at the overall EAEU level should be based on stronger legal grounds that include transparent requirements for doing business and greater market integration. And a priority task here is to involve businesses into development of specific regulation that takes into account needs of certain consumer groups; efficiency of specific mechanisms for protection of "vulnerable" customers depends on whether a solution to this task is found.

A consumer exposed to increased risks can never actively participate in economic relations associated with production development. As N.I. Golub notes in his research, "the greater consumption is, the more demanding people are to conditions of labor, life, and work" [1]. For example, when assessing people's life and health (on the basis of expenses spent on providing proper life conditions and health), American experts estimated "a price of life" as being equal to $1.5-3.0$ million US dollars; German experts, $0.5-1.0$ million US dollars; experts from the Moscow Institution for Issues of Nuclear Energy Development of the Russian Academy of Science, 0.090.19 million US dollars [14].

Marketing research on consumer behavior tends to focus on an individual consumer. Peculiarities and needs of an individual consumer are examined in order to get commercial benefits. Such examinations should be aimed at providing "vulnerable" consumers with a possibility to make safe deals without any high consumer risks; deals that can bring additional revenues to businesses.
For example, as D.G. Alekseeva rightly points out, there are spheres where a risk to lose business reputation is especially high. Nowadays there are risks caused by new hazards for lending organizations credibility in relation to changes in the essence and conditions of bank operations; these risks can lead to a loss of business reputation. It makes financial organizations take additional measures aimed at providing safety of such consumer deals ${ }^{4}$ [15]. Expenses on providing safety are incomparable with profits brought by concluding safe deals.

Variability of consumer risks determines multiple approaches to managing such risks that should include social, legal, and economic aspects. On the unified EAEU market, management of such risks can be optimized only provided that all the countries, businesses, and communities take active part in the process. Efficiency of a risk-based approach to providing consumer rights is recognized and validated on the international level [16]. The common goal of protecting vulnerable consumer groups should be a possibility for each representative of such groups to completely fulfill his or her consumer rights. This goal can be achieved in the EAEU only if encouragement and protection of vulnerable consumers' rights becomes subject to specific legal regulation on the interstate level.

This approach will make for implementation of protection for socially vulnerable consumer groups and will become one of the most significant components in common work done by the EAEU member states on creation of as comfortable and safe consumer environment for socially vulnerable population groups as only possible.

Funding. Our research was not granted any sponsors' support.

A conflict of interests. The authors state there is no conflict of interests.

\section{References}

1. Golub N.I. Klassifikatsiya riskov v lichnom potreblenii [Classification of risks related to private consumption]. Sotsiologicheskie issledovaniya, 1999, no. 8, pp. 139-141 (in Russian).

${ }^{4}$ The strategy for increasing financial availability in the Russian Federation in 2018 - 2020 (approved by the Board of Directors of the Central Bank of Russia on March 26, 2018). KonsultantPlus. Available at: http://www.consultant.ru/document/cons_doc LAW 295167/ (access date: 08.06. 2018) (in Russian). 
2. Heuze V. Une reconsideration du principe de reparation integrale. Cycle Risques, assurances, responsabilite - Groupe de travail sur «Incertitude et reparation», Cour de Cassation. Paris, 2005. Available at: https://www.courdecassation.fr/venements 23/colloques activites formation_4/2005_2033_publique_incertitude_8058.himl (16.11.2014).

3. Robentson Thomas S. Consumer behavior. Cambridge, Harvard University, 1999, 800 p.

4. Vasilenko I.V., Tkachenko O.V. Sotsial'nyi risk: k opredeleniyu ponyatii [Social risk: to the definition of the concept]. Vestnik Volgogradskogo gosudarstvennogo universiteta, 2014, no. 3, pp. 32-45 (in Russian).

5. Zabolevaniya pishchevogo proiskhozhdeniya [Food-related diseases]. Vsemirnaya organizatsiya zdravookhraneniya: ofitsial'nyi sait. Available at: http://www.who.int/foodsafety/areas_work/foodbornediseases/ru/ (08.06.2018) (in Russian).

6. Protecting consumers in a globalised world: time for a global approach to product safety? Consumers International: ofitsial'nyi sait. Available at: https://www.consumersinternational.org/newsresources/blog/posts/a-global-approach-to-product-safety/ (08.06.2018).

7. World report on disability. World Health Organization. Available at: http://www.who.int/disabilities/world_report/2011/report/en/ (08.06.2018).

8. 10 faktov ob invalidnosti [10 facts about disability]. Vsemirnaya organizatsiya zdravookhraneniya: ofitsial'nyi sait. Available at: http://www.who.int/features/factfiles/disability/ru/ (08.06.2018) (in Russian).

9. 10 faktov o starenii i zdorov'e [10 facts about growing old and health]. Vsemirnaya organizatsiya zdravookhraneniya: ofitsial'nyi sait. Available at: http://www.who.int/features/factfiles/ageing/ageing facts/ru/ (08.06.2018) (in Russian).

10. Psikhicheskoe zdorov'e i pozhilye lyudi [Mental health and elderly people]. Vsemirnaya organizatsiya zdravookhraneniya: ofitsial'nyi sait. Available at: http://www.who.int/mediacentre/factsheets/fs381/ru/ (08.06.2018) (in Russian).

11. Antonyan S.S., Imaeva G.R., Aimaletdinov T.A., Korkonosova E.I., Buimuratova L.R., Sharova O.A., Tomilova O.V. Finansovoe povedenie pozhilykh lyudei v Rossii v kontekste digitalizatsii: Issledovanie CGAP/NAFI [Financial behavior of elderly people in Russia in the context of digitalization: research performed by CGAP/NAFR (National Agency for Financial Research)]. Available at: https://wciom.ru/fileadmin/file/nauka/grusha2017/prez/24 antonyan.pdf (08.06.2018) (in Russian).

12. Slater D. Consumer Culture \& Modernity. Cambridge, Polity Press, 1998, 139 p.

13. Resolution adopted by the General Assembly on 22 December 2015: 70/186 Consumer protection. Available at: http://unctad.org/en/PublicationsLibrary/ditccplpmisc2016d1_ru.pdf (08.06.2018).

14. Korchagin V.P., Narozhnaya V.L. Ekonomicheskaya otsenka ushcherba ot lyudskikh poter' [Economic assessment of damages caused by population losses]. Problemy prognozirovaniya, 1998, no. 5, pp. 112 (in Russian).

15. Alekseeva D.G. Bezopasnoe osushchestvlenie bankovskoi deyatel'nosti: pravovye problemy [Safe banking activities: legal issues]. Bankovskoe pravo, 2011, no. 1, pp. 35-40 (in Russian).

16. Better regulation in Europe: Executive summaries. OECD, 2010, 157 p. Available at: www.oecd.org/gov/regulatory-policy/45079126.pdf $(08.06 .2018)$.

Osaulenko L.N. Vulnerability as a specific category of consumer risk. Health Risk Analysis, 2018, no. 3, pp. 24-30. DOI: 10.21668/health.risk/2018.3.03.eng

Received: 20.06 .2018

Accepted: 09.07.2018

Published: 30.09 .2018 